Health, 2021, 13, 2-2

\title{
In Mourning and Memory of Late Professor Kuo-Chen Chou (2)
}

\section{Siew Yim Loh}

University of Malaya, Malaysia

Email: syloh@um.edu.my

Prof. Kuo-Chen Chou was a highly cited researcher listed by Clarivate Analytics (2014-2018). He was a biophysicist, and bioinformatician with numerous contributions to science, and has been Health's Honorary Editor-in-Chief. He was affiliated with the Gordon Life Science Institute, (a non-profit research organization in Boston that he founded) until his recent passing. A scientist who is a biophysicist, he studied the physical principles of living things and their biological processes on cell development, growth, heredity, and disease; and his contribution towards this unique field is enhanced with his bioinformatics training, enabling scientists to better predict and study certain drug molecule binding within a protein. His significant progress was the use of graphical approaches to study biological problems to provide insights for analyzing complicated mechanisms, has generated a graphic rules proposed by him and his co-workers (widely known as Chou's graphic rules), and is widely used, example in studying change in liver glucokinase in a non-steady-state, inhibition of HIV-1 reverse transcriptase, drug metabolism systems. Prof. Chou's work has left a legacy that will be continued by younger scientists.

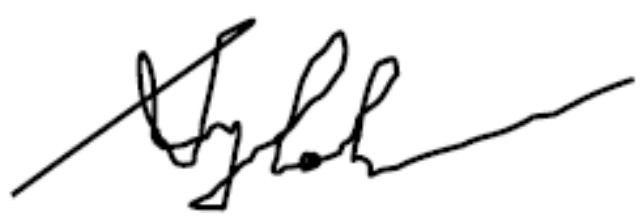

Assoc. Prof. Siew Yim Loh

Editorial Member of journal HEALTH

How to cite this paper: Loh, S.Y. (2021) In Mourning and Memory of Late Professor Kuo-Chen Chou (2). Health, 13, $2-2$. https://dx.doi.org/10.4236/health.2021.137A002

Received: July 12, 2021; Published: July 16, 2021

Copyright $\odot 2021$ by author(s) andScientificResearch Publishing Inc.This work is licensed under the CreativeCommons Attribution International License (CC BY 4.0). http://creativecommons.org/licenses/by/4.0/ 